\title{
ANALISIS SUMBER-SUMBER PENDAPATAN ASLI DAERAH TERHADAP PENDAPATAN ASLI DAERAH DI KABUPATEN/KOTA WLAYAH PROVINSI JAWA BARAT
}

\author{
Oleh: \\ Aristanti Widyaningsih \\ (Dosen Program Studi Akuntansi Fakultas Pendidikan Ekonomi \& Bisnis UPI) \\ Amy Srimartina \\ (Alumni Program Studi Akuntansi Fakultas Pendidikan Ekonomi \& Bisnis UPI)
}

\begin{abstract}
Abstrak
Tujuan yang ingin dicapai dari penelitian ini yaitu untuk mengetahui seberapa besar pengaruh sumber-sumber PAD (pajak daerah, retribusi daerah, hasil perusahaan milik daerah dan hasil pengelolaan kekayaan daerah yang dipisahkan serta lain-lain PAD yang sah) terhadap PAD di kabupaten/kota wilayah Provinsi Jawa Barat secara individu. Jenis data yang digunakan dalam penelitian ini dikategorikan sebagai data sekunder yang diperoleh dari laporan hasil pemerikasaan atas laporan keuangan pemerintah daerah kabupaten/kota wilayah Provinsi Jawa Barat yang telah diaudit oleh BPK. Sejalan dengan tujuan penelitian maka metode penelitian yang digunakan adalah metode korelasional dan untuk menganalisis permasalahan dalam penelitian ini digunakan alat analisis korelasi produk momen Pearson dan korelasi ganda yang nantinya diukur koefisien determinasi dari tiap variable independen terhadap variabel dependen. Hasil penelitian ini menunjukkan bahwa secara individu pajak daerah memberikan kontribusi positif terhadap $\mathrm{PAD}$ dengan tingkat hubungan sangat kuat $(0,941)$, retribusi daerah memberikan kontribusi positif terhadap PAD dengan tingkat hubungan sangat kuat $(0,829)$, hasil perusahaan daerah dan hasil pengelolaan kekayaan daerah lainnya yang dipisahkan memberikan kontribusi positif terhadap PAD dengan tingkat hubungan sedang $(0,445)$, serta lain-lain PAD yang sah memberikan kontribusi positif terhadap PAD dengan tingkat hubungan sedang $(0,436)$.
\end{abstract}

Kata Kunci: Pendapatan Asli Daerah

\section{Latar Belakang}

Setelah beberapa dekade pola sentralisasi dianut oleh Bangsa Indonesia. Namun semenjak tahun 2001 pola tersebut berganti dengan pola baru yang disebut desentralisasi atau yang lebih dikenal sebagai otonomi daerah. Sistem pemerintahan Republik Indonesia menganut asas desentralisasi, dekonsentrasi dan tugas pembantuan yang dilaksanakan secara bersama-sama. Untuk mewujudkan pelaksanaan asas desentralisasi tersebut maka dibentuk daerah otonom yang terbagi dalam daerah provinsi, daerah kabupaten dan daerah kota yang bersifat otonom sesuai dengan ketentuan pasal 1 ayat (1) UndangUndang Nomor 12 Tahun 2008 tentang Perubahan Kedua atas Undang-Undang Nomor 32 Tahun 2004 tentang Pemerintahan Daerah.

Menurut pasal 1 dalam Undang-Undang tersebut dirumuskan bahwa "Daerah Otonom", selanjutnya disebut daerah, adalah kesatuan masyarakat hukum yang mempunyai batas daerah tertentu berwenang mengatur dan mengurus kepentingan masyarakat menurut prakarsa sendiri berdasarkan aspirasi masyarakat dalam ikatan Negara Kesatuan Republik Indonesia.

Mardiasmo (2004:46) mengemukakan bahwa misi utama pelaksanaan otonomi daerah dan desentralisasi fiskal sekurang-kurangnya ada tiga, yaitu (1) meningkatkan kualitas dan kuantitas pelayanan publik dan kesejahteraan masyarakat, (2) menciptakan efisiensi dan efektifitas pengelolaan sumber daya daerah, serta (3) memberdayakan dan 
menciptakan ruang bagi masyarakat untuk berpartisipasi dalam proses pembangunan. Sedangkan tujuan utama penyelenggaraan otonomi daerah adalah untuk meningkatkan pelayanan publik (public service) dan memajukan perekonomian daerah.

Berdasarkan Undang-Undang Nomor 12 Tahun 2008 tentang Perubahan Kedua atas Undang-Undang Nomor 32 Tahun 2004 tentang Pemerintahan Daerah, serta UndangUndang Nomor 25 Tahun 1999 yang kemudian direvisi menjadi Undang-Undang Nomor 33 Tahun 2004 tentang Perimbangan Keuangan Antara Pemerintah Pusat dan Daerah membawa perubahan yang mendasar pada tata pemerintahan dan sistem keuangan baik pemerintah pusat maupun daerah. Perubahan tata pemerintahan tersebut terwujud dalam bentuk pemberian otonomi daerah dan desentralisasi fiskal kepada pemerintahan daerah.

Dewasa ini terdapat beberapa permasalahan yang dihadapi pemerintah daerah dalam hal keuangan seperti yang dikemukakan Hirawan (dalam Irianto, 2005:2) yaitu pertama, sebagian besar dari penerimaan daerah berasal dari sumbangan atau subsidi pemerintahan pusat yang tercermin dari besarnya anggaran rutin melalui subsidi otonomi daerah. Kedua, rendahnya kemampuan daerah untuk menggali sumber-sumber asli daerahnya. Ketiga, kurangnya usaha dan kemampuan pemerintah daerah dalam mengelola dan menggali sumber-sumber pendapatan yang ada. Keempat, masalah kurangnya kesadaran masyarakat dalam membayar pajak, retribusi dan pungutan lainnya.

Dalam rangka meningkatkan kemampuan keuangan daerah agar dapat melaksanakan otonomi daerah, pemerintah melakukan berbagai kebijakan perpajakan daerah, diantaranya dengan melakukan berbagai kebijakan perpajakan daerah, salah satunya dengan menetapkan Undang-Undang Nomor 34 Tahun 2000 tentang perubahan atas Undang-Undang Nomor 18 Tahun 1997 tentang Pajak Daerah dan Retribusi Daerah. Pemberian kewenangan dalam pengenaan pajak daerah dan retribusi daerah diharapkan dapat lebih mendorong pemerintah daerah untuk terus berupaya mengoptimalkan pendapatan asli daerah (PAD), khususnya yang berasal dari pajak daerah dan retribusi daerah.

Pajak daerah, retribusi daerah, hasil perusahaan milik daerah dan hasil pengelolaan kekayaan daerah yang dipisahkan, serta lain-lain PAD yang sah yang merupakan sumber-sumber PAD adalah salah satu bentuk peran serta masyarakat dalam menyelenggarakan otonomi daerah serta merupakan sumber pendapatan daerah yang penting untuk membiayai penyelenggaraan pemerintahan dan pembangunan daerah. Sumber-sumber pendapatan asli daerah tersebut merupakan sumber pendapatan yang sepenuhnya dapat direncanakan atau ditargetkan dan direalisasikan oleh pemerintah daerah.

Idealnya sumber penerimaan utama daerah adalah yang berasal dari PAD, sedangkan grants hanya diposisikan sebagai penutup celah antara kapasitas fiskal (fiscal capacity) dan kebutuhan fiskal (fiscal needs). Namun data menunjukan proporsi PAD hanya mampu membiayai belanja pemerintah daerah paling tinggi sebesar $20 \%$. Bahkan kenyataan tersebut terjadi baik pada era sebelum maupun sesudah era otonomi daerah dan desentralisasi fiskal (Haryo Kuncoro dalam R. Dian Hardian, 2004:3). Jadi jelas bahwa kontribusi PAD terhadap belanja daerah masih relatif kecil hanya 20\% sedangkan $80 \%$ sumber pembiayaan lain masih tergantung pada sumber lain seperti dana yang bersumber dari dana perimbangan dan pinjaman daerah.

Demikian pula di kabupaten/kota yang ada di Jawa Barat, untuk menunjang pelaksanaan otonomi daerah atau penyelenggaraan pemerintah, pembangunan dan pelayanan kepada masyarakat pemerintah kabupaten/kota yang ada di Jawa Barat perlu menggali potensi pendapatan daerah seoptimal mungkin yang kemudian dikelola oleh dinas pendapatan daerah yang ada di kabupaten/kota daerah masing-masing yang ada di Jawa Barat.

Sampai dengan akhir tahun 2008, Jawa Barat memiliki 26 kabupaten/kota daerah otonomi. Dikarenakan laporan keuangan daerah tahun 2008 untuk seluruh kabupaten/kota 
dalam keuangan daerah yang merupakan salah satu tolak ukur di dalam pelaksanaan otonomi daerah yang luas, nyata, dan bertanggung jawab secara proporsional.

\section{Rumusan Masalah}

1) Seberapa besar pangaruh pajak daerah terhadap PAD di kabupaten/kota wilayah Provinsi Jawa Barat?

2) Seberapa besar pengaruh retribusi daerah terhadap PAD di kabupaten/kota wilayah Provinsi Jawa Barat?

3) Seberapa besar pengaruh pendapatan hasil perusahaan milik daerah dan hasil pengelolaan kekayaan daerah lainnya yang dipisahkan terhadap PAD di kabupaten/kota wilayah Provinsi Jawa Barat?

4) Seberapa besar pengaruh lain-lain PAD yang sah terhadap PAD di kabupaten/kota wilayah Provinsi Jawa Barat?

\section{Kerangka Pemikiran}

Berdasarkan ketetapan MPR Nomor XV/MPR/1998 tentang Penyelenggaraan Otonomi Daerah, Pengaturan dan Pemanfaatan Sumber Daya Nasional yang Berkeadilan serta Perimbangan Keuangan Pusat dan Daerah, pemerintah telah mengeluarkan paket kebijakan tentang otonomi daerah yaitu:

1. Undang-Undang Nomor 12 Tahun 2008 tentang Perubahan Kedua atas UndangUndang Nomor 32 Tahun 2004 tentang Pemerintahan Daerah.

2. Undang-Undang Nomor 25 Tahun 1999 yang kemudian direvisi menjadi UndangUndang Nomor 33 Tahun 2004 tentang Perimbangan Keuangan Pemerintah Pusat dan Daerah.

Konsekuensi dari pelaksanaan kedua Undang-Undang tersebut adalah daerah harus mampu mengatur dan mengelola rumah tangganya sendiri dalam upaya penyelenggaraan pemerintahan dan pelayanan kepada masyarakat yang disebut sebagai otonomi daerah. Secara etimologis, menurut Tangkilisan (2005:32) otonomi daerah diartikan sebagai memerintah sendiri. Sedangkan secara terminologis, Sarundajang (dalam Tangkilisan, 2005:33) mendefinisikan otonomi sebagai hak dan kewajiban daerah untuk mengatur dan mengurus rumah tangganya sendiri sesuai dengan perundangundangan yang berlaku.

Otonomi daerah agar dapat dilakukan secara nyata dan bertanggung jawab seperti yang diterapkan pemerintah pusat terhadap pemerintah daerah perlu ditindaklanjuti dengan melaksanakan serangkaian kegiatan guna memenuhi kebutuhan daerah dengan cara menggali potensi daerah dan pengelolaan keuangan daerah yang berorientasi kepada kepentingan dan kebutuhan masyarakat. Penerimaan daerah perlu terus diupayakan adanya peningkatan PAD dengan menggali sumber-sumber yang ada sehingga dapat menyelenggarakan pemerintahan, pembangunan dan pelayanan masyarakat yang semakin meningkat kuantitas dan kualitasnya. Upaya perbaikan sangat diperlukan terutama di bidang pengelolaan keuangan daerah.

Dalam pelaksanaan otonomi daerah ini, Kaho (dalam Halim, 2004:127) menyatakan bahwa daerah harus mempersiapkan sumber daya manusia yang baik, faktor keuangan yang cukup, faktor peralatan yang memadai serta faktor organisasi dan menejemen yang baik. Diantara faktor-faktor tersebut, salah satu faktor yang memegang peranan penting adalah faktor keuangan. Istilah keuangan ini menurut Tangkilisan (2005:65) mengandung arti "setiap hak yang berhubungan dengan masalah uang, yang antara lain berupa sumber pendapatan, jumlah uang yang cukup dan pengelolaan keuangan yang sesuai dengan tujuan dan peraturan yang berlaku".

Faktor keuangan ini sangat penting peranannya dalam suatu pemerintahan daerah, karena dapat menentukan keberhasilan dalam menciptakan kemandirian daerah tersebut. 
Sebagaimana diungkapkan oleh Nasarudin (dalam Halim, 2004:187) mengenai dua ciri utama yang menunukkan suatu daerah yang mampu melaksanakan otonomi, yaitu (1) kemampuan keuangan daerah artinya kewenangan dan kemampuan dalam menggali, mengelola dan menggunakan sumber-sumber keuangannya sendiri, serta (2) ketergantungan yang seminimal mungkin terhadap bantuan dari pemerintah pusat sehingga PAD menjadi sumber keuangan yang terbesar.

Pemungutan sumber-sumber pendapatan yang dimiliki oleh suatu daerah akan berbeda antara satu daerah dengan daerah yang lainnya, karena menurut Abimanyu (2005:4) disebabkan adanya perbedaan kondisi ekonomi, sumber daya alam, tingkat pengangguran dan jumlah penduduk. Dengan demikian masing-masing daerah perlu mengoptimalkan penggalian dan pengelolaan potensi yang terbatas ini agar dapat mencapai tujuannya dalam melayani dan menciptakan kesejahteraan masyarakat. Pemungutan sumber pendapatan daerah ini diatur dalam Bab IV Undang-Undang Nomor 12 Tahun 2008 tentang Perubahan Kedua atas Undang-Undang Nomor 32 Tahun 2004 tentang Pemerintahan Daerah, Bab VIII tentang keuangan daerah pasal 157 serta dalam Bab IV Undang-Undang Nomor 33 Tahun 2004 tentang Perimbangan Keuangan antara Pemerintah Pusat dan Daerah pasal 5, disebutkan bahwa sumber pendapatan daerah terdiri dari PAD, dana perimbangan, pinjaman daerah serta lain-lain pendapatan daerah yang sah.

PAD merupakan sumber pendapat murni daerah. Sebagaimana diatur dalam Undang-Undang Nomor 25 Tahun 1999 yang kemudian direvisi menjadi Undang-Undang Nomor 33 Tahun 2004 tentang Perimbangan Keuangan Pusat dan Daerah, sumbersumber PAD kabupaten/kota terdiri dari:

1. Hasil Pajak Daerah;

2. Hasil Retribusi Daerah;

3. Hasil perusahaan milik daerah dan hasil pengelolaan kekayaan daerah lainnya yang dipisahkan (antara lain: bagian laba, deviden, dan penjualan saham milik daerah);

4. Lain-lain Pendapatan Asli Daerah yang sah (antara lain hasil penjualan aset tetap Daerah dan Jasa giro).

Semua pendapatan daerah itu mempunyai peranan penting dalam keuangan daerah yang merupakan salah satu tolok ukur di dalam pelaksanaan otonomi daerah yang luas, nyata, dan bertanggung jawab secara proporsional.

Upaya optimalisasi penerimaan daerah akan berjalan dengan baik apabila pemerintah daerah memiliki kinerja yang baik. Hal ini disebabkan karena sumber-sumber penerimaan tersebut berasal dari uang rakyat (money public) yang nantinya harus dapat dipertanggungjawabkan baik secara vertical accountability maupun horizontal accountability yakni pertanggungjawaban kepada legislatif daerah, eksekutif daerah serta masyarakat. Dengan demikian diperlukan suatu analisis yang komprehensif terhadap sisi penerimaan untuk menilai kinerja pemerintah daerah dalam mengoptimalkan sumber penerimaan tersebut.

Simanjuntak (dalam Halim, 2004:92) menyatakan bahwa yang dimaksud dengan analisis penerimaan adalah analisis mengenai kemampuan pemerintah daerah dalam menggali sumber-sumber pendapatan potensial dan biaya-biaya yang dikeluarkan untuk meningkatkan pendapatan tersebut. Keuangan daerah yang berhasil dari sisi penerimaan adalah keuangan daerah yang mampu meningkatkan penerimaan daerah secara berkesinambungan seiring dengan perkembangan perekonomian daerah.

Secara sederhana, kerangka pemikiran dari penelitian ini digambarkan sebagai berikut: 


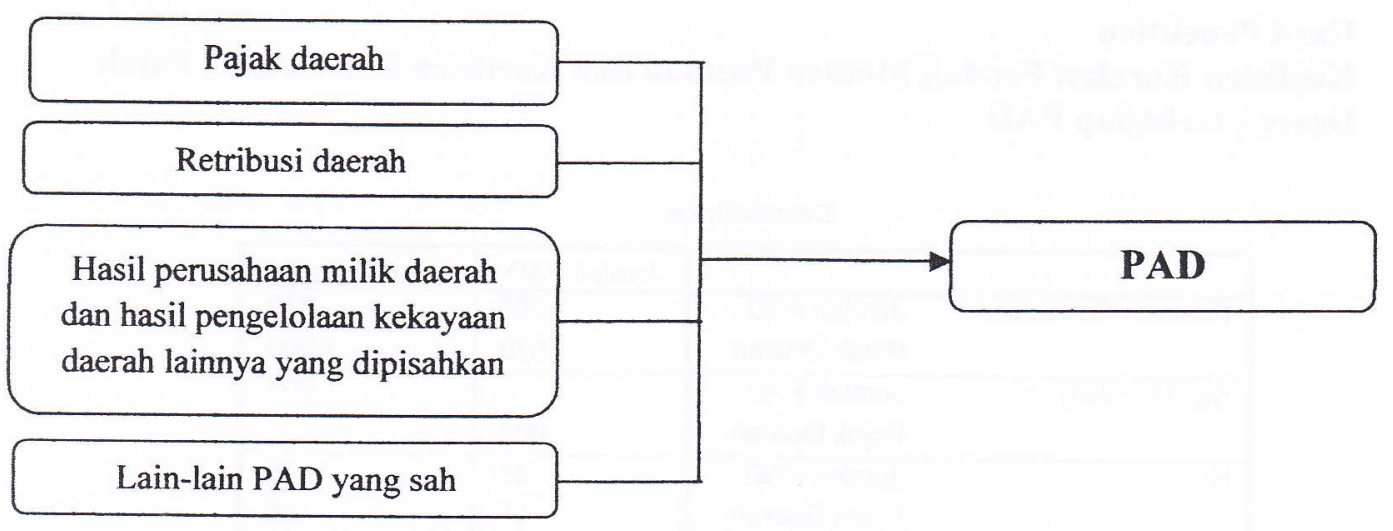

\section{Metode Penelitian}

Metode penelitian yang digunakan dalam penelitian ini adalah penelitian verifikatif. Suharsimi Arikunto (2006:8) mengemukakan bahwa "penelitian verifikatif pada dasarnya ingin menguji kebenaran pengumpulan data di lapangan". Penelitian verifikatif ini bertujuan untuk mengetahui seberapa besar pengaruh pajak daerah, retribusi daerah, hasil perusahaan milik daerah dan hasil pengelolaan kekayaan daerah lainnya yang dipisahkan serta lain-lain PAD yang sah secara individu maupun secara bersamasama terhadap penerimaan PAD di kabupaten/kota wilayah Provinsi Jawa Barat. Metode penelitian yang digunakan dalam penelitian ini menggunakan pendekatan kuantitatif sebab data yang diperoleh merupakan data kuantitatif. Selanjutnya data yang diperoleh tersebut akan diolah, dianalisis dan diproses lebih lanjut dengan menggunakan dasardasar teori yang telah dipelajari.

Dalam penelitian ini yang menjadi populasi adalah seluruh kabupaten/kota yang ada di Jawa Barat yang telah memiliki laporan keuangan daerah untuk tahun anggaran 2007 yang telah menjalani proses audit oleh pihak Badan Pemeriksa Keuangan (BPK) yaitu sebanyak 25 kabupaten/kota. Pengambilan data dilakukan dengan teknik sampel jenuh. Teknik sampel jenuh adalah teknik penentuan sampel bila semua anggota populasi digunakan sebagai sampel. (Sugiyono, 2007:122). Dikarenakan sampel yang digunakan adalah sampel jenuh, sesuai dengan pengertian mengenai sampel jenuh tersebut, maka sampel penelitian adalah seluruh kabupaten/kota yang ada di wilayah Provinsi Jawa Barat yang telah memiliki laporan keuangan daerah untuk tahun anggaran 2007 yang telah menjalani proses audit oleh pihak Badan Pemeriksa Keuangan (BPK) yaitu sebanyak 25 kabupaten/kota.

Untuk menjawab pertanyaan yang diungkapkan dalam rumusan masalah, maka alat analisis data yang digunakan dalam penelitian ini adalah metode statistik. Sebelum melakukan pengujian hipotesis terhadap data yang dianalisis, perlu dilakukan pengujian asumsi klasik. Uji asumsi klasik diperlukan untuk memaksimalkan keakuratan dalam hasil pengolahan data. Adapun uji asumsi klasik yang perlu dilakukan adalah uji normalitas. 


\section{Hasil Penelitian \\ Koefisien Korelasi Produk Momen Pearson dan Koefisien Determinasi Pajak Daerah terhadap PAD}

\begin{tabular}{|c|c|c|c|}
\hline \multicolumn{4}{|c|}{ Correlations } \\
\hline & & Jumlah PAD & Pajak Daerah \\
\hline \multirow[t]{2}{*}{ Pearson Correlation } & Jumlah PAD & 1.000 & .970 \\
\hline & Pajak Daerah & .970 & 1.000 \\
\hline \multirow[t]{2}{*}{ Sig. (1-tailed) } & Jumlah PAD & . & .000 \\
\hline & Pajak Daerah & .000 & \\
\hline \multirow[t]{2}{*}{$N$} & Jumlah PAD & 25 & 25 \\
\hline & Pajak Daerah & 25 & 25 \\
\hline
\end{tabular}

\begin{tabular}{|l|r|r|r|r|r|}
\hline Model Summary & \multicolumn{1}{c|}{$\begin{array}{c}\text { Adjusted } \\
\text { Durbir- } \\
\text { Watson }\end{array}$} \\
\hline Model & $R$ & R Square & $\begin{array}{c}\text { Std Eror of the } \\
\text { Estimate }\end{array}$ & \begin{tabular}{c} 
R Square \\
\hline 1
\end{tabular} \\
\hline
\end{tabular}

a. Predictors: (Constant), Pajak Daerah

b. Dependent Variable: Jumlah PAD

Berdasarkan hasil perhitungan SPSS 12.0 dapat terlihat bahwa koefisien korelasi yang terjadi antara pajak daerah terhadap PAD adalah sebesar 0,97. Dan pada tabel selanjutnya terlihat bahwa koefisien determinasi yang terjadi antara pajak daerah terhadap PAD adalah sebesar 0,941. Berdasarkan hasil perhitungan tersebut, dan dengan melihat tabel interpretasi koefisien korelasi, menunjukkan bahwa hubungan antara pajak daerah terhadap PAD sangat kuat.

\section{Koefisien Korelasi Produk Momen Pearson dan Koefisien Determinasi Retribusi Daerah terhadap PAD}

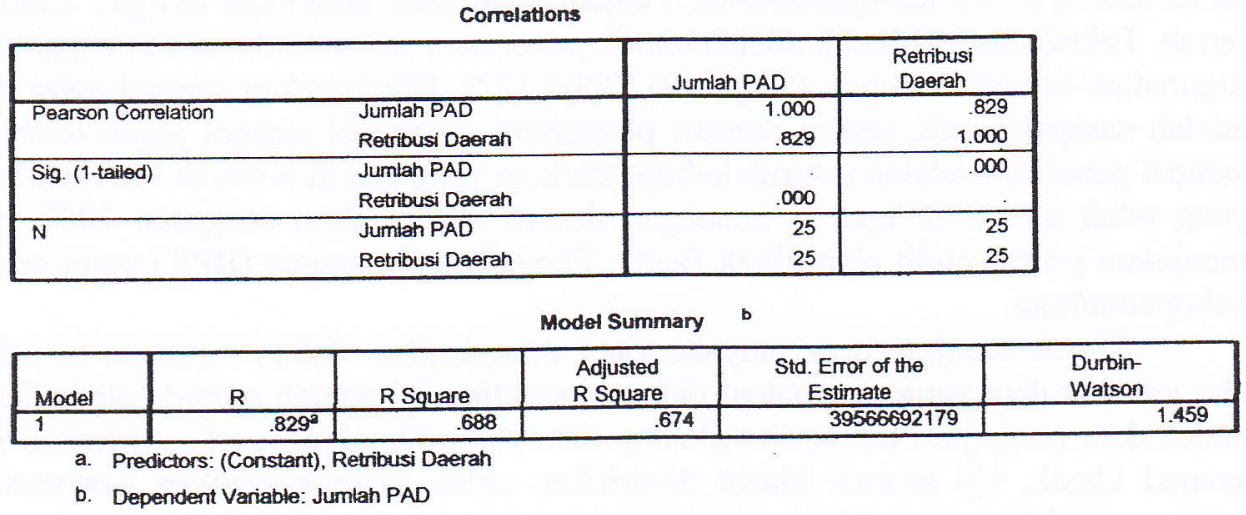

Berdasarkan hasil perhitunganSPSS 12.0 dapat terlihat bahwa koefisien korelasi yang terjadi antara retribusi daerah terhadap PAD adalah sebesar 0,829. Dan pada tabel selanjutnya terlihat bahwa koefisien determinasi yang terjadi antara retribusi daerah terhadap PAD adalah sebesar 0,688. Berdasarkan hasil perhitungan tersebut, dan dengan melihat tabel interpretasi koefisien korelasi, menunjukkan bahwa hubungan antara retribusi daerah terhadap $\mathrm{PAD}$ adalah sangat kuat. 


\section{Hasil Penelitian \\ Koefisien Korelasi Produk Momen Pearson dan Koefisien Determinasi Pajak Daerah terhadap PAD}

\begin{tabular}{|c|c|c|c|}
\hline \multicolumn{4}{|c|}{ Correlations } \\
\hline & & Jumlah PAD & Pajak Daerah \\
\hline \multirow[t]{2}{*}{ Pearson Correlation } & Jumlah PAD & 1.000 & .970 \\
\hline & Pajak Daerah & .970 & 1.000 \\
\hline \multirow[t]{2}{*}{ Sig. (1-tailed) } & Jumlah PAD & . & .000 \\
\hline & Pajak Daerah & .000 & \\
\hline \multirow[t]{2}{*}{$\mathrm{N}$} & Jumlah PAD & 25 & 25 \\
\hline & Pajak Daerah & 25 & 25 \\
\hline
\end{tabular}

\begin{tabular}{|l|r|r|r|r|r|}
\hline Model & R & R Square & $\begin{array}{c}\text { Adjusted } \\
\text { R Square }\end{array}$ & $\begin{array}{c}\text { Std. Error of the } \\
\text { Estimate }\end{array}$ & $\begin{array}{c}\text { Durbin- } \\
\text { Watson }\end{array}$ \\
\hline 1 & $970^{\mathrm{a}}$ & .941 & .938 & 17190984196.00 & 1.465 \\
\hline
\end{tabular}

a. Predictors: (Constant), Pajak Daerah

b. Dependent Variable: Jumlah PAD

Berdasarkan hasil perhitungan SPSS 12.0 dapat terlihat bahwa koefisien korelasi yang terjadi antara pajak daerah terhadap PAD adalah sebesar 0,97. Dan pada tabel selanjutnya terlihat bahwa koefisien determinasi yang terjadi antara pajak daerah terhadap PAD adalah sebesar 0,941 . Berdasarkan hasil perhitungan tersebut, dan dengan melihat tabel interpretasi koefisien korelasi, menunjukkan bahwa hubungan antara pajak daerah terhadap PAD sangat kuat.

\section{Koefisien Korelasi Produk Momen Pearson dan Koefisien Determinasi Retribusi Daerah terhadap PAD}

\begin{tabular}{|c|c|c|c|}
\hline \multicolumn{4}{|c|}{ Comelations } \\
\hline & & Jumbah PAD & $\begin{array}{l}\text { Retribusi } \\
\text { Daerah }\end{array}$ \\
\hline \multirow[t]{2}{*}{ Pearson Comelation } & Jumlah PAD & 1.000 & .829 \\
\hline & Retribusi Daerah & .829 & 1.000 \\
\hline \multirow[t]{2}{*}{ Sig. (1-tailed) } & Jumlah PAD & & .000 \\
\hline & Retribusi Daerah & .000 & \\
\hline \multirow[t]{2}{*}{$N$} & Jumtah PAD & 25 & 25 \\
\hline & Retribusi Daerah & 25 & 25 \\
\hline
\end{tabular}

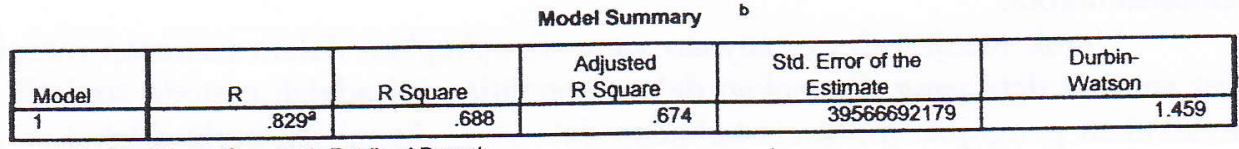

a. Predictors: (Constant), Retribusi Daerah

b. Dependent Variable: Jumlah PAD

Berdasarkan hasil perhitunganSPSS 12.0 dapat terlihat bahwa koefisien korelasi yang terjadi antara retribusi daerah terhadap PAD adalah sebesar 0,829. Dan pada tabel selanjutnya terlihat bahwa koefisien determinasi yang terjadi antara retribusi daerah terhadap PAD adalah sebesar 0,688. Berdasarkan hasil perhitungan tersebut, dan dengan melihat tabel interpretasi koefisien korelasi, menunjukkan bahwa hubungan antara retribusi daerah terhadap $\mathrm{PAD}$ adalah sangat kuat. 


\section{Koefisien Korelasi Produk Momen Pearson dan Koefisien Determinasi Hasil Perusahaan Milik Daerah dan Hasil Pengelolaan Kekayaan Daerah Lainnya yang Dipisahkan terhadap PAD}

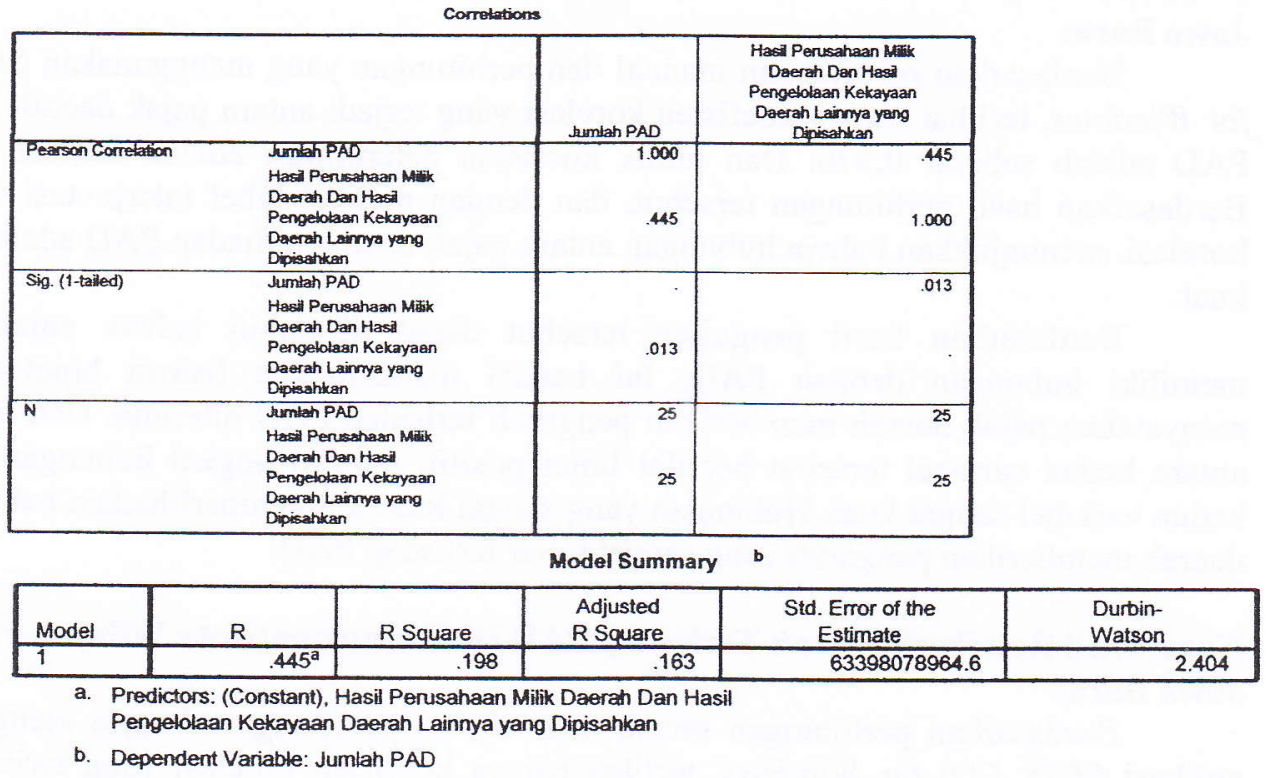

Berdasarkan hasil perhitungan SPSS 12.0 dapat terlihat bahwa koefisien korelasi yang terjadi antara hasil perusahaan milik daerah dan hasil pengelolaan kekayaan daerah lainnya yang dipisahkan terhadap PAD adalah sebesar 0,445. Dan pada tabel selanjutnya terlihat bahwa koefisien determinasi yang terjadi antara hasil perusahaan milik daerah dan hasil pengelolaan kekayaan daerah lainnya yang dipisahkan terhadap PAD adalah sebesar 0,198 . Berdasarkan hasil perhitungan tersebut, dan dengan melihat tabel interpretasi koefisien korelasi, menunjukkan bahwa hubungan antara hasil perusahaan milik daerah dan hasil pengelolaan kekayaan daerah lainnya yang dipisahkan terhadap PAD adalah sedang.

\section{Koefisien Korelasi Produk Momen Pearson dan Koefisien Determinasi Lain-Lain PAD yang Sah terhadap PAD}

\begin{tabular}{|ll|r|r|}
\hline \multicolumn{3}{|c|}{ Correlations } \\
\hline Pearson Correlation & Jumlah PAD & $\begin{array}{c}\text { PAD yg sah } \\
\text { lainnya }\end{array}$ \\
& Jumlah PAD & 1.000 & .436 \\
& PAD yg sah lainnya & .436 & 1.000 \\
\hline Sig. (1-tailed) & Jumlah PAD &. & .015 \\
& PAD yg sah lainnya & .015 &. \\
\hline N & Jumlah PAD & 25 & 25 \\
& PAD yg sah lainnya & 25 & 25 \\
\hline
\end{tabular}

\begin{tabular}{|l|r|r|r|r|r|}
\hline Model & \multicolumn{1}{|c|}{ Model Summary b } \\
\hline 1 & \multicolumn{1}{|c|}{ R Square } & $\begin{array}{c}\text { Adjusted } \\
\text { R Square }\end{array}$ & $\begin{array}{c}\text { Std. Error of the } \\
\text { Estimate }\end{array}$ & $\begin{array}{c}\text { Durbin- } \\
\text { Watson }\end{array}$ \\
\hline
\end{tabular}

a. Predictors: (Constant), PAD yg sah lainnya

b. Dependent Variable: Jumlah PAD

Berdasarkan hasil perhitungan SPSS 12.0 dapat terlihat bahwa koefisien korelasi yang terjadi antara lain-lain PAD yang sah terhadap PAD adalah sebesar 0,436 . Dan pada tabel selanjutnya terlihat bahwa koefisien determinasi yang terjadi antara lain-lain PAD yang sah terhadap PAD adalah sebesar 0,190. Berdasarkan hasil perhitungan 
tersebut, dan dengan melihat tabel interpretasi koefisien korelasi, menunjukkan bahwa hubungan antara lain-lain PAD yang sah terhadap PAD adalah sedang.

\section{Kontribusi Pajak Daerah Terhadap PAD Di Kabupaten/Kota Wilayah Provinsi Jawa Barat}

Berdasarkan perhitungan manual dan perhitungan yang menggunakan SPSS 12.0

for Windows, terlihat bahwa koefisien korelasi yang terjadi antara pajak daerah terhadap PAD adalah sebesar 0,970. Dan untuk koefisien determinasi adalah sebesar 94,11\%. Berdasarkan hasil perhitungan tersebut, dan dengan melihat tabel interpretasi koefisien korelasi, menunjukkan bahwa hubungan antara pajak daerah terhadap PAD adalah sangat kuat.

Berdasarkan hasil pengujian tersebut dapat diketahui bahwa pajak daerah memiliki hubungan dengan PAD. Ini berarti menunjukkan bahwa hipotesis yang menyatakan pajak daerah memberikan pengaruh terhadap PAD diterima. Dan hubungan antara kedua variabel tersebut bersifat linier positif, dengan tingkat hubungan diantara kedua variabel sangat kuat. Hubungan yang sangat kuat ini memperlihatkan bahwa pajak daerah memberikan pengaruh yang sangat besar terhadap PAD.

\section{Kontribusi Retribusi Daerah Terhadap PAD Di Kabupaten/Kota Wilayah Provinsi Jawa Barat}

Berdasarkan perhitungan secara manual dan perhitungan dengan menggunakan aplikasi SPSS 12.0 for Windows, terlihat bahwa koefisien korelasi yang terjadi antara retribusi daerah terhadap PAD adalah sebesar 0,829. Dan untuk koefisien determinasi sebesar 0,688. Berdasarkan hasil perhitungan tersebut, dan dengan melihat tabel interpretasi koefisien korelasi, menunjukkan bahwa hubungan yang terjadi adalah sangat kuat.

Berdasarkan hasil pengujian tersebut dapat diketahui bahwa retribusi daerah memiliki hubungan dengan PAD. Ini berarti menunjukkan bahwa hipotesis yang menyatakan retribusi daerah memberikan pengaruh terhadap PAD diterima. Dan hubungan antara kedua variabel tersebut bersifat linier positif, dengan tingkat hubungan diantara kedua variabel sangat kuat. Hubungan yang sangat kuat ini memperlihatkan bahwa realisasi retribusi daerah memberikan pengaruh yang sangat besar terhadap PAD yang terjadi di kabupaten/kota wilayah Provinsi Jawa Barat.

\section{Kontribusi Pendapatan Hasil Perusahaan Milik Daerah dan Hasil Pengelolaan Kekayaan Daerah Lainnya yang Dipisahkan Terhadap PAD Di Kabupaten/Kota Wilayah Provinsi Jawa Barat}

Berdasarkan perhitungan secara manual dan dengan menggunakan aplikasi SPSS 12.0 for Windows, terlihat bahwa koefisien korelasi yang terjadi antara hasil perusahaan milik daerah dan hasil pengelolaan kekayaan daerah lainnya yang dipisahkan terhadap PAD adalah sebesar 0,445. Untuk koefisien determinasi pada hasil perusahaan milik daerah dan hasil pengelolaan kekayaan daerah lainnya yang dipisahkan terhadap PAD adalah sebesar $19,83 \%$. Berdasarkan hasil perhitungan tersebut, dan dengan melihat tabel interpretasi koefisien korelasi, menunjukkan bahwa hubungan antara hasil perusahaan milik daerah dan hasil pengelolaan kekayaan daerah lainnya yang dipisahkan terhadap PAD adalah sedang.

Berdasarkan hasil pengujian tersebut dapat diketahui bahwa hasil perusahaan milik daerah dan hasil pengelolaan kekayaan daerah lainnya yang dipisahkan memiliki hubungan dengan PAD. Ini menunjukkan bahwa hipotesis yang menyatakan hasil perusahaan milik daerah dan hasil pengelolaan kekayaan daerah lainnya yang dipisahkan memberikan pengaruh terhadap PAD diterima. Dan hubungan antara kedua variabel tersebut bersifat linier positif, dengan tingkat hubungan diantara kedua variabel adalah 
sedang. Hubungan yang sedang ini memperlihatkan bahwa realisasi hasil perusahaan milik daerah dan hasil pengelolaan kekayaan daerah lainnya yang dipisahkan memberikan pengaruh yang sedang terhadap PAD.

\section{Kontribusi Lain-Lain PAD yang Sah Terhadap PAD Di Kabupaten/Kota Wilayah Provinsi Jawa Barat}

Berdasarkan perhitungan secara manual dan dengan menggunakan aplikasi SPSS 12.0 for Windows, terlihat bahwa koefisien korelasi yang terjadi antara lain-lain PAD yang sah terhadap PAD adalah sebesar 0,436. Dan untuk korelasi determinasi pada lainlain PAD yang sah adalah sebesar 0,190. Berdasarkan hasil perhitungan tersebut, dan dengan melihat tabel interpretasi koefisien korelasi, menunjukkan bahwa hubungan antara lain-lain PAD yang sah terhadap PAD adalah sedang.

Berdasarkan hasil pengujian tersebut dapat diketahui bahwa lain-lain PAD yang sah memiliki hubungan dengan PAD. Ini berarti menunjukkan bahwa hipotesis yang menyatakan lain-lain PAD yang sah memberikan pengaruh terhadap PAD diterima. Dan hubungan antara kedua variabel tersebut bersifat linier positif, dengan tingkat hubungan diantara kedua variabel adalah sedang. Hubungan yang sedang ini memperlihatkan bahwa realisasi lain-lain $\mathrm{PAD}$ yang sah memberikan pengaruh sedang terhadap PAD.

\section{Simpulan}

1. Pajak daerah memberikan pengaruh terhadap PAD. Dengan tingkat hubungan antara kedua variabel tersebut sangat kuat, maka pajak daerah memiliki pengaruh yang sangat kuat pula terhadap PAD.

2. Retribusi daerah memberikan pengaruh terhadap PAD. Dengan tingkat hubungan antara kedua variabel tersebut sangat kuat, maka retribusi daerah memiliki pengaruh yang sangat kuat terhadap PAD

3. Hasil perusahaan milik daerah dan hasil pengelolaan kekayaan daerah lainnya yang dipisahkan memberikan pengaruh terhadap PAD. Dengan tingkat hubungan antara kedua variabel tersebut adalah sedang, maka hasil perusahaan milik daerah dan hasil pengelolaan kekayaan daerah lainnya yang dipisahkan memiliki pengaruh yang sedang terhadap PAD.

4. Lain-lain PAD yang sah memberikan pengaruh terhadap PAD. Dengan tingkat hubungan antara kedua variabel tersebut adalah sedang, maka lain-lain PAD yang sah memiliki pengaruh yang sedang terhadap PAD.

\section{Saran}

1. Pemerintah daerah kabupaten/kota wilayah Provinsi Jawa Barat, khususnya Dinas Pendapatan Daerah terus menggali potensi pendapatan asli daerah masing-masing agar pendapatan asli daerah dapat dapat bertambah besar dari adanya penambahan potensi sumber PAD yang baru.

2. Pemerintah daerah kabupaten/kota wilayah Provinsi Jawa Barat, khususnya Dinas Pendapatan Daerah tetap mengoptimalkan sumber-sumber PAD yang telah ada sebelumnya agar targetan PAD di kabupaten/kota masing-masing daerah terus meningkat seiring dengan terus meningkatnya pertumbuhan ekonomi.

3. Bagi penelitian selanjutnya, hasil penelitian ini dapat dijadikan acuan untuk melakukan penelitian lanjutan dengan memperluas wilayah penelitian dan/atau memperpanjang periode waktu pengamatan penelitian agar bahasan yang diteliti menjadi lebih luas cakupannya. 
Daftar Pustaka

Abdul Halim. (2002). Akuntansi Sektor Publik, Akuntansi Keuangan Daerah. Jakarta: PT Salemba Empat. . (2004). Manajemen Keuangan Daerah. Yogyakarta: UPP AMP YKPN. (2007). Pengelolaan Keuangan Daerah. Yogyakarta: UPP STIM YKPN.

Badan Koordinasi Promosi dan Penanaman Modal Daerah (BKPPMD). Geografi Kabupaten/Kota di Provinsi Jawa Barat. [Online]. Tersedia: http://www.westjavainvest.com/in/index.php?option=com content\&task=view\&id = 79\&Itemid $=36$. [29 Agustus 2009]

Badan Pusat Statistik Jawa Barat. (2005). Jumlah Penduduk Menurut Wilayah, Kelompok Umur dan Jenis Kelamin Tahun 2005 (Hasil Survei Sosial Ekonomi Daerah 2005). [Online]. Tersedia: http://jabar.bps.go.id/Tabel/jumlah\%20penduduk.htm. [29 Agustus 2009]

Badan Pemeriksa Keuangan Republik Indonesia. (2008). Laporan Hasil Pemeriksaan atas Laporan Keuangan Pemerintah Kabupaten Bandung Tahun Anggaran (TA) 2007. [Online]. Tersedia: http://www.bpk.go.id/doc/hapsem/2007i/disc2/APBD/184_Kab_Bandung_LK.pdf.

Dinas Pendapatan Daerah Kabupaten Bandung. (2007). Laporan Realisasi Anggaran Tahun Anggaran 2007. Bandung: Dinas Pendapatan Daerah Kota Bandung.

Dinas Pendapatan Daerah Kota Bandung. (2007). Laporan Realisasi Anggaran Tahun Anggaran 2007. Bandung: Dinas Pendapatan Daerah Kota Bandung.

Elita Dewi. (2002). Identifikasi Sumber Pendapatan Asli Daerah dalam Rangka Pelaksanaan Otonomi Daerah. FISIP USU [online]. Tersedia: http://digilib.usu.ac.id/download/fe/manajemen-elita.pdf. [23 Agustus 2009].

Eneng Siti Komariah. (2009). Analisis Efektivitas Penerimaan Pajak Hotel dan Kontribusinya Terhadap Pendapatan Asli Daerah (PAD) Dalam Rangka Kemandirian Daerah Pada Kota Bandung. Skirpsi. Bandung: Universitas Pendidikan Indonesia.

Imam Ghozali. (2006). Aplikasi Analisis Multivariate dengan Program SPSS. Semarang: Badan Penerbit UNDIP

Indra Bastian. (2002). Akuntansi Sektor Publik. Yogyakarta: BPFE Yogyakarta.

Kesit Bambang Prakosa. (2005). Pajak dan Retribusi Daerah. Yogykarta: UI Press.

M. Nazir. (2003). Metode Penelitian. Jakarta: Ghalia Indonesia.

Mahmudi. (2007). Manajemen Kinerja Sektor Publik. Yogyakarta: UPP STIM YKPN.

Mardiasmo. (2002). Akuntansi Sektor Publik. Yogyakarta: Andi. . (2004). Otonomi dan Manajemen Keuangan Daerah. Yogyakarta: Andi.

Memen Kustiawan. (2005). Ringkasan Disertasi Pengaruh Faktor Pendorong dan Faktor Penghambat terhadap Peran dan Orientasi Pemerintah Daerah dalam Mengoptimalkan PAD (Survey pada Pemerintahan Provinsi Jowa Barat). Bandung: Universitas Padjadjaran.

Nila Permata Sari. (2006). Analisis Keberhasilan Penerimaan Pendapatan Asli Daerah Kota Bandung Tahun 2001-2004. Skripsi. Bandung: Universitas Pendidikan Indonesia.

Nur Indrianto dan Bambang Soepomo. (2002). Metodelogi Penelitian Bisnis. Yogyakarta: BPFE.

Provinsi Jawa Barat. Kabupaten/Kota Wilayah Provinsi Jawa Barat. [Online]. Tersedia: http://www.jabarprov.go.id/jabar/public/33393/kabkot default.htm.

R. Dian Hardian. (2008). Analisis Potensi dan Efektifitas Retribusi Parkir pada Unit Pelayanan Perparkiran (UPP) Kota Bandung. Skripsi. Bandung. Universitas Pendidikan Indonesia. 
Republik Indonesia. (2000). Peraturan Pemerintah Republik Indonesia Nomor 105 Tahun 2000 tentang Pengelolaan Pertanggungjawaban Keuangan Daerah. [Online]. Tersedia: http://www.usdrp-indonesia.org/files/downloadContent/419.pdf.

Republik Indonesia. (2001). Peraturan Pemerintah Nomor 65 Tahun 2001 tentang Pajak Daerah. [Online]. Tersedia:

http://www.setneg.go.id/components/com perundangan/docviewer.php?id=683\&file name=PP_No 65 th 2001.pdf.

Republik Indonesia. (2001). Peraturan Pemerintah Nomor 66 Tahun 2001 tentang Retribusi Daerah. [Online]. Tersedia:

http://www.setneg.go.id/components/com_perundangan/docviewer.php?id=685\&file name $=$ PP No 66 th 2001.pdf.

Republik Indonesia. (1962). Undang-Undang Nomor 5 Tahun 1962 tentang Perusahaan Daerah. [Online]. Tersedia:

http://legislasi.mahkamahagung.go.id/docs/UU/1962/UU\%20NO\%205\%20TH\%201 962.pdf.

Republik Indonesia. (2000). Undang-Undang Nomor 34 Tahun 2000 tentang Perubahan atas Undang-Undang Nomor 18 Tahun 1997 tentang Pajak Daerah dan Retribusi Daerah. [Online]. Tersedia:

http://www.setneg.go.id/components/com_perundangan/docviewer.php?id=243\&file name $=$ UU no 34 th 2000.pdf.

Republik Indonesia. (2003). Undang-Undang Republik Indonesia Nomor 17 Tahun 2003 tentang Keuangan Negara. [Online]. Tersedia:

http://www.setneg.go.id/components/com_perundangan/docviewer.php?id=320\&file name $=$ UU_no 17 th 2003.pdf.

Republik Indonesia. (2004). Undang-Undang Nomor 33 Tahun 2004 tentang Perimbangan Keuangan Antara Pemerintah Pusat dan Daerah. [Online]. Tersedia:http://www.setneg.go.id/components/com perundangan/docviewer.php?id= 366\&filename $=$ UU no 33 th 2004.pdf.

Republik Indonesia. (2008). Undang-Undang Nomor 12 Tahun 2008 tentang Perubahan Kedua Undang-Undang 32 Tahun 2004 tentang Pemerintahan Daerah. [Online]. Tersedia:

http://www.setneg.go.id/components/com perundangan/docviewer.php?id=1985\&fil ename=UU\%2012\%20Tahun $\% 202008$.pdf.

Rostika. (2009). Kontribusi Penerimaan Pajak Reklame terhadap Pendapatan Asli Daerah di Kabupaten Bandung Tahun 2003-2007. Skripsi. Bandung. Universitas Pendidikan Indonesia.

Sraun, Markus. (2005). "Potensi Penerimaan Retribusi Pasar Sragon dan Wosi di Kabupaten Manokwari”. Tesis. Yogyakarta: Universitas Gajah Mada.

Sudjana. (1997). Statistika II. Bandung: Tarsito.

Sugiyono. (2000). Statistika untuk Penelitian. Bandung: Alfabeta. (2006). Metode Penelitian Bisnis. Bandung: Alfabeta. (2007). Metode Penelitian Bisnis. Bandung: Alfabeta.

Suharsimi Arikunto. (2002). Prosedur Penelitian Suatu Pendekatan Praktek. Jakarta: Rineka Cipta.

Rineka Cipta.

. (2006). Prosedur Penelitian Suatu Pendekatan Praktek Jakarta:

Tangkilisan, Hessel Nogi S. (2005). Manajemen Publik. Jakarta: PT Grasindo.

Yossi Irianto. (2005). Optimalisasi Pajak dan Retribusi Daerah dalam Rangka Meningkatkan Kemampuan Keuangan Daerah. Bandung: Dinas Pendapatan Daerah Kota Bandung. 